\title{
COMPARATIVE CAREER ACCOMPLISHMENTS OF TWO DECADES OF WOMEN AND MEN DOCTORAL GRADUATES IN EDUCATION
}

\author{
Joan S. Stark, Malcolm A. Lowther, and Ann E. Austin
}

Patterns of doctoral study and subsequent career progress were compared for 756 men and women doctoral graduates in education at a research university from two six-year periods, one before and one after a rapid nation-wide increase in the percentage of women doctorates. Despite advantages relative to men in admission, financial support and full-time study, women doctorates of both periods had achieved less career progress than men but held similarly positive perceptions concerning career impact of the degree. Work experience prior to doctoral study strongly predicted career progress for both genders. Thus, affirmative action may have positively affected the careers of recent women doctorates who were younger and who began study with less established careers than women doctorates prior to 1970 .

Over the past two decades, dramatic sex role changes have occurred which have social, occupational, and educational implications. Although equal rights advocates remain unsatisfied, and affirmative action has not overcome status and salary differentials between the genders, changing college enrollment patterns demonstrate that women are aspiring to higher levels of education and entering fields of endeavor formerly dominated by men (Randour, Strausberg, and Lipman-Blumen, 1982). One consequence of the increasing number of women seeking advanced education is an expanding body of research focusing on the differences in educational experiences of male and female students during graduate study (Solmon, 1973; Berg and Ferber, 1983).

Understandably, in order to assess progress toward assimilation of female students, many such studies have focused on fields in which male students

Joan S. Stark and Malcolm A. Lowther, School of Education, The University of Michigan; Ann E. Austin, Oklahoma State University.

Research in Higher Education

(C) 1985 Agathon Press, Inc.

Vol. 22 , No. 3 
traditionally have been the majority. Although more women are seeking advanced education in traditionally female fields as well (Roemer, 1983), gender-related differential treatment of graduate students in such fields has been investigated less frequently. Furthermore, researchers have given little specific attention to the comparative career progress of men and women holding advanced degrees in traditionally female fields. Studies of career progress using data aggregated across disciplines and fields of work have provided evidence that, when compared to men, women who possess doctorates are disadvantaged in salaries and available job opportunities throughout their careers (Centra, 1976; Ferber and Kordick, 1978). Generally, women's opportunities in male-dominated fields are believed to have improved. However, no studies known to the authors provide recent comparisons of career progress of men and women in traditionally female fields. Perhaps it is tacitly assumed that women's opportunities for substantially responsible career positions in such fields will automatically increase in proportion to the number of those qualified.

Our study addresses these issues by examining both educational experiences during graduate study and subsequent career progress of men and women doctoral graduates in the traditionally female field of education. Two broad questions are investigated: (1) Do women and men doctoral students in education pursue graduate study under similar conditions? (2) Are women doctoral graduates making career progress similar to that of men graduates?

As will be illustrated shortly, the proportion of women receiving doctoral degrees in education has increased rather dramatically since 1970. In order to provide an assessment of whether enhanced career progress has accompanied the increasing proportion of highly qualified women in education, we have compared the career progress of men and women from two cohorts of doctoral graduates separated by a decade. The graduates in the first decade received their degrees just prior to initiation of affirmative action programs and prior to the rapid increase in the proportion of women receiving doctorates; graduates in the second group received degrees 10 years later, after affirmative action programs had been in place for several years.

\section{PROPORTIONS OF WOMEN IN EDUCATION GRADUATE STUDY AND EMPLOYMENT}

Although education has traditionally been considered a female-dominated field, based on the proportion of public school teachers who are women, only recently has the number of women actually equalled or exceeded the number of men as degree recipients at every level. To illustrate, although the total number of bachelor's degrees in education has declined 


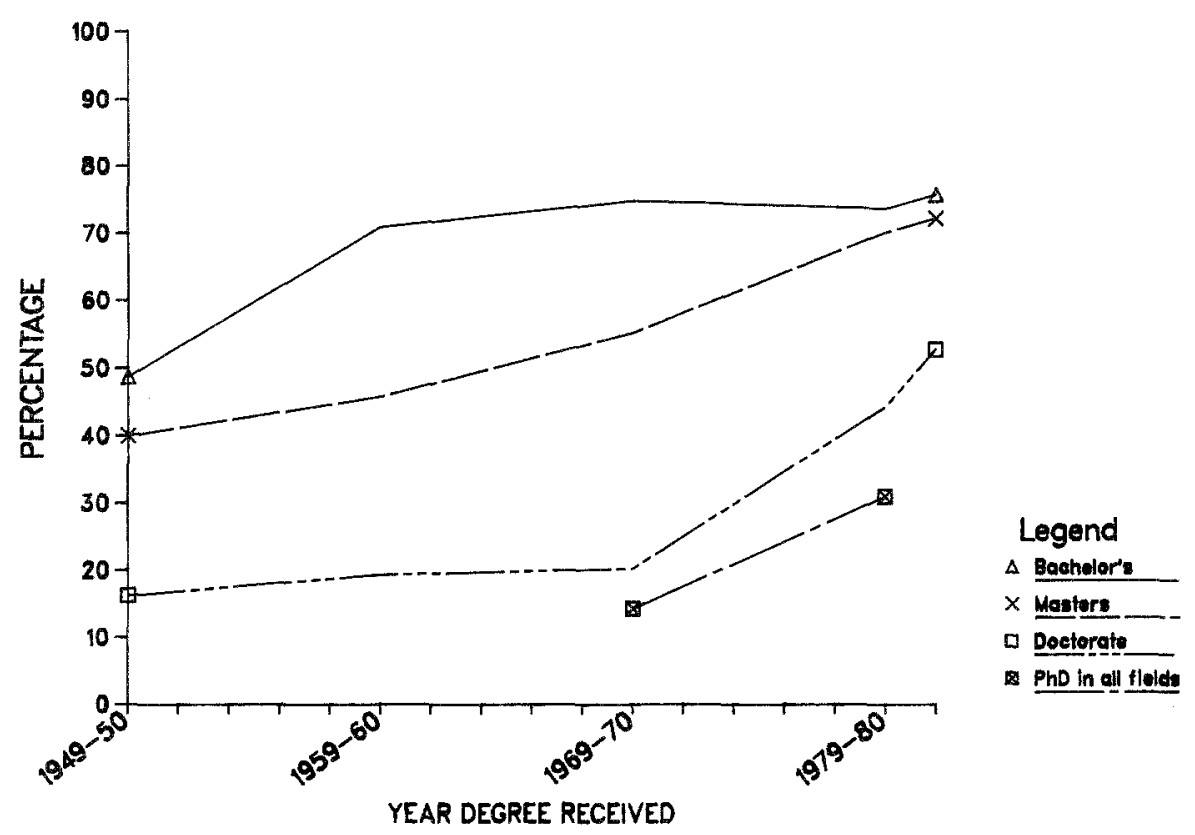

FIG. 1. Percentage of degrees in education granted to women, nationally 1949-50 to $1981-82$.

nearly $30 \%$ in recent years, the proportion of these degrees granted to women has increased from $48.9 \%$ in $1949-50$ to $75.9 \%$ in $1981-82$. As shown in Figure 1, women's proportion of master's degrees in education (often required for permanent teacher certification or continued employment) has grown slowly since 1949-50 until, in 1981-82, it approximated the proportion of bachelor's degrees.'

A different growth pattern characterized the percentage of doctoral degrees in education granted to women from 1949-50 to 1981-82. During the first two decades of this period, the proportion of women receiving doctorates increased slowly from $14 \%$ to $20 \%$. The increase after 1970 was much more rapid, and by $1981-82$, women received about half of the doctoral degrees awarded in education. After 1970, the increase in education doctorates granted to women was more rapid than the increase in the proportion of doctorates granted to women in all fields over the same period. As Roemer (1983) points out, while women students recently have redistributed themselves into previously male-dominated fields, they simultaneously have increased their share of advanced degrees in those fields which they previously dominated only at the bachelor's level.

Although women have comprised more than half of the career educators 
in the public schools for many decades, they have not been well represented in administrative and leadership posts (Biklen and Brannigan, 1980). In the mid-1970s, $19 \%$ of men employed in elementary education and $8 \%$ of men in secondary education were school principals, whereas the comparable proportions of women at each of these levels who were principals was $1 \%$ or less (Hanscot and Tyack, 1982). In colleges and universities, the relatively small percentage and lower status of women in the professorial ranks overall has been well-documented (Tidball, 1976; Denmark, 1978; Broschart, 1978; Ekstrom, 1979; Gappa and Uehling, 1979; Hornig, 1980; Ahren and Scott, 1981). As in other traditionally female fields, such as home economics, nursing, and library science, a higher percentage of education professors are women, but men continue to hold the majority of professorial posts. Furthermore, fewer than $10 \%$ of the deans of education in the United States are women.

The data presented above demonstrate that higher educational aspirations of women have been clearly evidenced in the field of education since 1969. It is reasonable to assume that such educational aspirations are matched by higher career aspirations. Available employment data show considerable room for documentation of career progress by women holding advanced degrees in education as their numbers and availability increase.

\section{REVIEW OF RELATED RESEARCH}

\section{Gender Differences in Graduate Study}

Numerous recent studies have examined the relative status of the sexes in programs of graduate study. Differentials in graduate student financial support for men and women students have been identified, possibly based on a greater likelihood that men will enter fields of study where financial assistance is more readily available (Lorang and Terenzini, 1982; Berg and Ferber, 1983). Men and women students report experiencing educational environments of varying supportiveness in history but not in psychology (Harnett 1981) and in the physical/biological sciences as compared with education (Berg and Ferber, 1983). Men and women graduate students have reported different levels of stress associated with doctoral study in three groups of fields which the researcher classified as "female minority, female majority and egalitarian" (Holahan, 1979).

In spite of the predominant emphasis on gender, one investigator, who examined support needs among students over 25 years of age, inferred that needs for psychological support during collegiate study may be related more strongly to student age and family situation than to gender alone. (Malin et al., 1980). This inference was based on evidence that men students beyond 
traditional college age experienced greater conflicts between study and noneducational responsibilities than did women students while simultaneously receiving less family support and encouragement in their studies. Although the study focused on undergraduates, the results seem applicable to education graduate students who are likely to be above age 25 and have family responsibilities. Berg and Ferber (1983) suggested that men graduate students may be disadvantaged in obtaining support in a traditionally female field such as education. One potential reason for such disadvantage could be the burden of family financial responsibilities which require maintenance of regular employment in the absence of fellowships or assistantships.

Another source of student support often considered to be important during graduate study involves close relationships with faculty. Varying ratios of the sexes among faculty members who serve as role models in different fields may affect the supportiveness of the environment for men and women students (Tidball, 1976). Although empirical evidence seems scarce, nearly all researchers reporting negative educational climates for women have inferred the need for additional women faculty members to provide mentorship. The slightly higher proportion of women faculty members in education, as compared with most fields of study, suggests that women education graduate students may find such collegial relationships possible.

\section{Gender Differences in Postdoctoral Career Patterns}

Among the broader studies comparing careers of men and women receiving doctorates are those of Centra (1975), who studied men and women receiving doctorates in 1950, 1960, and 1968, and of Ferber and Kordick (1978), who studied gender differentials in earnings of Ph.D.s graduating from 1958 to 1963 and from 1967 to 1971 . These two studies encompassed varied disciplines and employment settings, and both reported that women doctorates reaped fewer employment benefits than their male colleagues. Although women took only slightly more frequent furloughs from the labor market, initial salary gaps widened over 15 to 20 years. For both sexes, years of work experience prior to the Ph.D. positively affected earnings after the degree was received. In analyzing their results, Ferber and Kordick reported that women receiving the $\mathrm{Ph} . \mathrm{D}$. in the more recent decade they examined (late 1960s) were older, on the average, than men; that a higher proportion was married than had been true for the decade of the late 1950s; and that these women tended to subordinate their careers to their husbands' job mobility, which may partially explain their lower salaries. An alternate conclusion was drawn by Shann (1983) who found women in traditionally female fields to have less ambitious career plans than men; possibly they have been willing to settle for less financially rewarding careers. 
A recent follow-up study (Berg and Ferber, 1983) involving a 1979 survey of men and women graduate students at the University of Illinois who had been enrolled at any time from 1968-1975 provides slight evidence that women graduates are not entirely content with their career options. Based on an overall $39 \%$ response rate of both masters and doctoral students, $25 \%$ of men graduates were satisfied with job opportunities and salary offers, compared to $19 \%$ of women graduates. Other studies have also concluded that career aspirations of women doctorates have not been fully met. The results of such studies must be applied with caution in education, as investigators frequently appear to presume that doctoral work directly follows college graduation, that doctoral students pursue study on a full-time basis, that new doctorates have no prior work experience and that entrance to a college or university academic career is the graduate's preference if not the norm (see, for example, Wong and Sanders, 1983). These conditions tend not to be true for either men or women education doctoral graduates.

\section{SCOPE OF THE STUDY}

For our investigation of educational experiences and subsequent careers of men and women doctoral recipients, we used data available from a follow-up study of graduates who had received doctoral degrees in education at a large public university during the periods $1964-70$ and 1974-80. We pursued several specific questions suggested by the research just reviewed and subsidiary to the two broad questions stated earlier. Although the comprehensiveness of our list of research questions was limited by the types of measures available in the existing data set, ${ }^{2}$ we were able to compare men and women graduates in each of two decades and same-gender graduates across decades with respect to sources of financial assistance and supportive faculty associations during doctoral study. With regard to subsequent career progress, it was possible to compare both reported career progress subsequent to the degree and the degree of satisfaction expressed by the graduates regarding the impact of the degree on various aspects of their careers. Lastly, we were able to explore for education doctoral graduates both the common assumption that full-time study (without need for maintenance of employment) has a positive effect on subsequent career progress and the suggestion made by previous researchers (Ferber and Kordick, 1978) that career progress may be strongly influenced by previous work experience. Thus, our findings fill a void in the literature about gender discrimination during graduate study and subsequent career progress in a traditionally female field. The discussion of measures and analysis of data are organized according to the specific research questions listed below: 
1. Do women and men doctoral students in education pursue graduate study under similar conditions? That is, are there gender-related differences among doctoral graduates in education with respect to:

a. age at receipt of degree

b. employment patterns and related sources of financial support during graduate study

c. patterns of collegiality among faculty and students

2. Are women doctoral graduates making career progress similar to that of men graduates?

a. Are there gender-related differences with respect to:

1. careers pursued following receipt of the degree

2. career changes following the degree

3. perceptions of career progress after receiving the degree

4. Are gender-related differences in career patterns or perceptions of career progress related to age when degree was received, source of financial support during degree study, or career experience before study?

b. If gender-related career patterns exist, are they consistent for graduates over the two decades of the 1960s and 1970s before and after a rapid rise in the proportion of women doctorates?

\section{METHOD}

All individuals receiving doctoral degrees in education at a large public research university during the years 1964 through $1970(N=469)$ and 1974 through $1980(N=923)$ were surveyed. Responses were received from 258 graduates of the $1964-70$ period (57\%) and from 505 graduates of the 1974-80 period $(55 \%)$ ). After eliminating respondents for whom year of graduation was uncertain, 756 responses $(54 \%$ of the total survey population) were available for analysis. To examine differences due to decade of graduation as well as sex, the sample was partitioned into four groups as shown in subsequent data tables.

As illustrated in Figure 2 below, the percentage of women doctoral graduates in education from this university followed national trends quite closely during the period after $1969-70$, when such statistics were maintained by the University. Although such records had not been kept for the 1960 s decade, our analysis sample for that period also appears close to the national percentage of women doctorates. Figure 2 illustrates that the mean percent of women over each six-year sample period approximates the national figure for the midpoint of the period. 


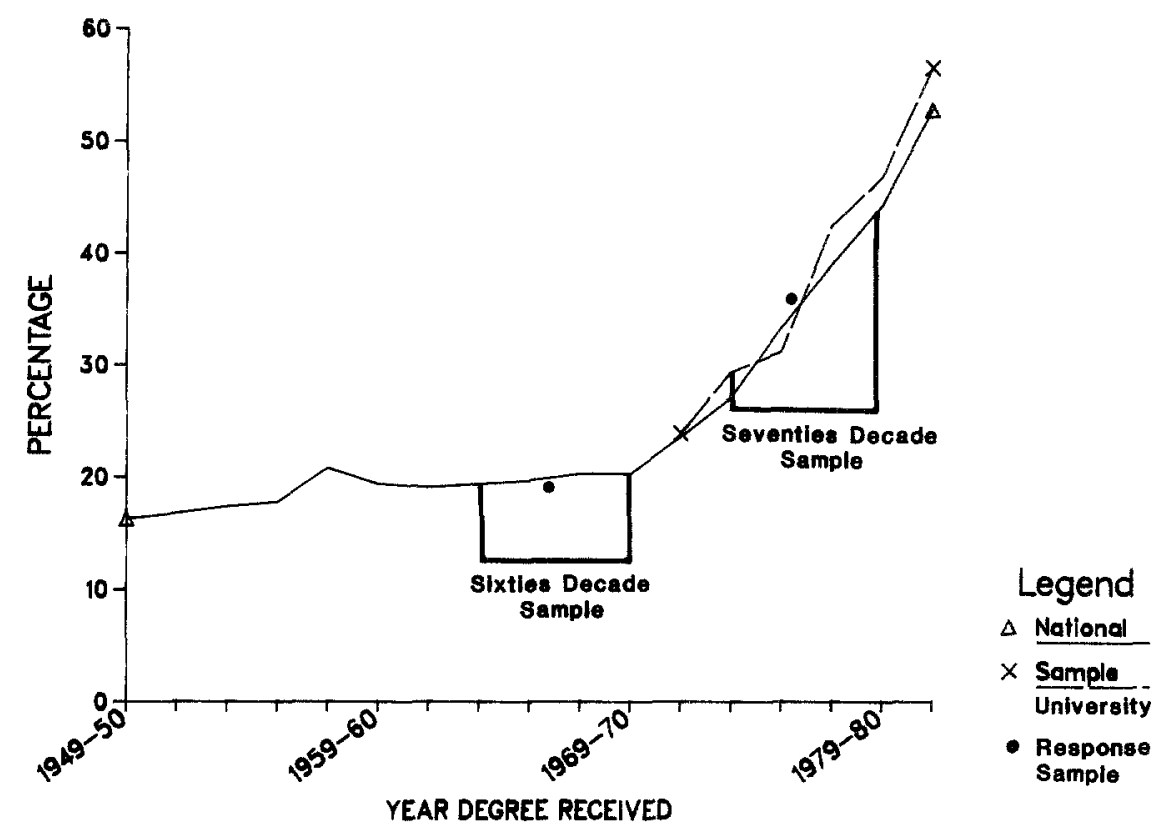

FIG. 2. Percentage of doctorate degrees in education granted to women, nationally and at sample university.

\section{Patterns of Study}

Measures used to compare study patterns of men and women are described briefly below.

\section{Demographic Information}

Available demographic information included sex, program of study, year of degree, and age at receipt of degree. Age was collected in four categories: 30 years or under; $31-40$ years; $41-50$ years; 51 years or over.

\section{Employment and Financial Support During Degree}

Graduates indicated their sources of financial support during each of two stages of doctoral study: coursework and dissertation. Choices ranged from full-time study with no employment, to various combinations of assistantships and professionally unrelated types of employment, to full-time employment concurrent with study. For more concise analysis and interpretation, we combined each respondent's answers to these several questions, and 
classified graduates into one of four patterns of work and study for each stage of doctoral work as follows:

Pattern 1: Full-time student with no employment

Pattern 2: Full-time student with graduate assistant employment

Pattern 3: Part-time student with part-time nongraduate assistant employment

Pattern 4: Part-time student with full-time employment.

Patterns 1 through 4 were chosen to represent a continuum from total involvement with the doctoral program, through study and/or sponsored employment, to full-time pursuit of usual employment with peripheral study. $^{3}$

Graduates also reported reasons for the type of financial support during each phase of doctoral work using one of two scales; one scale ranged from "preferred full-time employment" to "needed full-time employment"; the second scale provided options from "preferred part-time employment" to "needed part-time employment".

\section{Collegiality}

To obtain a proxy measure of gender-related collegial association, we compared the extent to which men and women graduate students stated that they remained in touch with same gender faculty members. Such a measure admittedly is based on an untested assumption that students remain in touch with faculty members who have been helpful through their graduate study. Since it may also be contaminated by geographic proximity and the differential attendance of faculty members at conferences also attended by graduates, it provides only a rough measure of gender-related collegiality.

\section{Career Patterns}

\section{Career Development Measures}

Graduates reported parallel employment information for (1) the position they held immediately prior to beginning doctoral study; (2) the two most professionally related positions they held during the coursework and dissertation stages of doctoral study, respectively; (3) the position they held immediately after receiving the doctoral degree; and (4) their current position. The information they supplied included: title of position, name of the institution or organization in which the position was held, a selection from one of six categories indicating the type of institution or organization (elementary or secondary education, higher education, community service organization, government agency, business, other); full- or part-time job status; and the number of years they held the position. 
We assigned one of 46 different codes to each job title. To compare career progress from this detailed information, we then assigned to each job title code, regardless of institutional setting, one of five occupational level indices (lowest $=1$; highest $=5$ ) based on the investigators' judgment of: (1) status; (2) responsibility, and (3) relatedness to career goals typically sought by education doctoral students. Lastly, we obtained a measure of occupational change by subtracting the occupational level index before doctoral study from the occupational level index at the time of the survey.

The specific job titles, their classifications, and the occupational level indices assigned are shown in Appendix 1 along with the percent of graduates, by gender and decade, holding the positions before the doctorate and at the time of the survey. Although two of the three investigators were able to agree on each occupational level index, there is room for difference of opinion regarding the "level" to be assigned to some positions. A university president and a superintendent of schools clearly are at the highest occupational level in their respective domains based on responsibility, status, and career relatedness. More ambiguity surrounds classification of consultants, researchers, media workers, private practitioners, and clergymen. Because the number of graduates employed in such positions was small, the overall picture of career change was minimally affected.

\section{Perceived Impact of the Doctorate on Career Development}

On a five-point Likert-type scale (ranging from $1=$ no change to $5=$ greatly increased), graduates judged "the extent to which receipt of the doctorate affected your career" in each of the following areas: professional responsibility, professional skills, professional knowledge, status or rank, salary, job security, and personal satisfaction. These responses were treated as seven separate interval-appearing scales for the purpose of our analysis.

\section{Analysis}

To summarize, the data used in this study included sex; program of study; age at receipt of degree; year degree was received; two four-category ordinal scales representing patterns of study and employment during each of the two stages of doctoral study; the percentage of male and female faculty members with whom male and female graduates remain in frequent contact; two nominal categories indicating the institutional settings in which the graduate was employed before doctoral study and at the time of the survey; two five-point occupational index scales indicating the status/responsibility/relatedness level of the graduate's employment before doctoral study and at the time of the survey; and, finally, seven five-point interval-appearing 
TABLE 1. Age of Women and Men Graduates at Receipt of Doctoral Degree

\begin{tabular}{|c|c|c|c|c|}
\hline \multirow[b]{2}{*}{ Age at Degree } & \multicolumn{2}{|c|}{$1964-70^{a}$} & \multicolumn{2}{|c|}{$1974-80^{b}$} \\
\hline & $\begin{array}{c}\text { Women } \\
\text { ( } \% \text { of } \\
\text { Sample) }\end{array}$ & $\begin{array}{c}\text { Men } \\
\text { ( } \% \text { of } \\
\text { Sample) }\end{array}$ & $\begin{array}{c}\text { Women } \\
\text { ( } \% \text { of } \\
\text { Sample) }\end{array}$ & $\begin{array}{c}\text { Men } \\
\text { (\% of } \\
\text { Sample) }\end{array}$ \\
\hline 30 or less & 7.8 & 19.4 & 17.2 & 21.3 \\
\hline 31 to 40 & 37.3 & 52.4 & 47.1 & 49.2 \\
\hline 41 to 50 & 33.3 & 25.2 & 23.0 & 25.1 \\
\hline \multirow[t]{2}{*}{51 or more } & 21.6 & 2.9 & 12.6 & 4.4 \\
\hline & \multicolumn{2}{|c|}{$X^{2}=27.61, p<.01$} & $X_{3}^{2}=11$. & $p<.01$ \\
\hline
\end{tabular}

Approximate mean age

in years ${ }^{c}$

42.4

36.7

38.6

36.8

$a_{N}=51$ women; 207 men.

${ }^{b} N=176$ women; 322 men.

cThe approximate mean age for each group was obtained by weighting the midpoints of frequency intervals and interpolating.

scales reflecting graduates' perceptions of the impact of the degree on various aspects of their careers. The statistical analysis included percentage comparisons, simple univariate statistics, and multiple regression. Details accompany the results.

\section{RESULTS}

The results of the study are organized by the research questions posed earlier.

\section{Patterns of Study}

\section{Student Age}

Table 1 describes the ages at receipt of the doctorate reported by men and women graduates of each decade. Women who received doctoral degrees in both decades were significantly older (nearly six years for the $1960 \mathrm{~s}$ decade) than their male peers.

Across decades, the age at receipt of the doctorate was constant for men graduates, whereas women in the 1970s completed doctorates nearly four years earlier than women in the $1960 \mathrm{~s}$. A higher percentage of women than men over age 50 and a lower percentage of women than men under 30 have 
TABLE 2. Patterns of Student Study and Employment During Two Stages of Doctoral Work

\begin{tabular}{|c|c|c|c|c|}
\hline & \multicolumn{2}{|c|}{$1964-70^{a}$} & \multicolumn{2}{|c|}{$1974-80^{b}$} \\
\hline & $\begin{array}{c}\text { Women } \\
\text { ( } \% \text { of } \\
\text { Sample) }\end{array}$ & $\begin{array}{c}\text { Men } \\
(\% \text { of } \\
\text { Sample })\end{array}$ & $\begin{array}{c}\text { Women } \\
(\% \text { of } \\
\text { Sample) }\end{array}$ & $\begin{array}{c}\text { Men } \\
(\% \text { of } \\
\text { Sample })\end{array}$ \\
\hline $\begin{array}{l}\text { Pattern during course } \\
\text { 1. Full-time student/ } \\
\text { no work } \\
\text { 2. Full-time student/ } \\
\text { graduate assistant } \\
\text { 3. Part-time student/ } \\
\text { part-time work } \\
\text { 4. Part-time student/ } \\
\text { full-time work }\end{array}$ & $\begin{array}{l}27.5 \\
27.5 \\
29.4\end{array}$ & $\begin{array}{c}22.4 \\
p=.73 \\
\text { Decades: }\end{array}$ & $\begin{array}{c}25.0 \\
X_{3}^{2}=6 \\
79, p=.0\end{array}$ & $\begin{array}{r}33.5 \\
p=.09\end{array}$ \\
\hline $\begin{array}{l}\text { Pattern during dissert } \\
\text { 1. Full-time student/ } \\
\text { no work } \\
\text { 2. Full-time student/ } \\
\text { graduate assistant } \\
\text { 3. Part-time student/ } \\
\text { part-time work } \\
\text { 4. Part-time student/ } \\
\text { full-time work }\end{array}$ & $\begin{array}{l}30.0 \\
22.0 \\
20.0 \\
28.0 \\
X_{3}^{2}=4\end{array}$ & $\begin{array}{c}30.1 \\
p=.19 \\
\text { Decades: }\end{array}$ & $\begin{array}{c}35.4 \\
34.9 \\
X_{3}^{2}=8 \\
94, p=.0\end{array}$ & $\begin{array}{r}10.1 \\
10.7 \\
42.3 \\
36.9 \\
p=.03\end{array}$ \\
\hline
\end{tabular}

$a_{N}=51$ women; 207 men.

${ }^{b} N=176$ women; 322 men.

received degrees in both decades, but the differences have narrowed considerably in recent years.

\section{Study Patterns and Sources of Financial Support}

The four patterns of study and employment during two stages of doctoral work are described for each of the subsamples in Table 2. In the 1970s the patterns of women differed significantly from those of men; women were more likely to be full-time students, particularly during the dissertation stage $\left(X_{3}^{2}=8.80, p=.03\right)$. Combining students with and without assistant- 
ships (Patterns 1 and 2), 55.0\% of the women students and $47.8 \%$ of the men were full-time students during the coursework stage in the 1960s; these percentages of full-time students decreased to $39.8 \%$ for women and $30.1 \%$ for men during the $1970 \mathrm{~s}$. During the dissertation stage, $52 \%$ of the women and $38.4 \%$ of the men were full-time students during the $1960 \mathrm{~s}$, decreasing to $29.7 \%$ of women and $20.8 \%$ of men during the $1970 \mathrm{~s}$. In the $1960 \mathrm{~s}$, $27.5 \%$ of all women graduates and $24 \%$ of all men graduates held assistantships during their doctoral coursework; these percentages decreased to $17.6 \%$ and $15.0 \%$ during the $1970 \mathrm{~s}$. Thus, as both the total number of doctoral students and the number of women pursuing doctoral study increased, the percentage of all doctoral students receiving financial support and pursuing full-time study decreased. Education doctoral students of both sexes were far more likely to study part time in the 1970s. Nonetheless, women maintained a somewhat greater share of available assistantships and more often pursued their study on a full-time basis. In reporting reasons for their study patterns during the 1960 s decade, $25.5 \%$ of the women and $28.0 \%$ of the men indicated they needed to maintain full-time employment for financial and family reasons. In the 1970 s decade a slightly greater proportion of the men compared to the women $(22 \%: 32 \%)$ said they needed to maintain their employment. The reason for the different proportion is not known. It may reflect: (1) more severe economic constraints for men with family responsibility in the 1970s; (2) decreased job mobility and opportunity for educational leave in the 1970s; or (3) fewer family responsibilities among the somewhat younger women students during this period.

\section{Field of Specialization}

Table 3 describes the fields of specialization reported by the doctoral students over the two decades. Because of program organizational changes over the two periods in the school where the study was conducted, we classified graduates according to programs that existed at the time of the 1982 survey. Varying admission standards and faculty availability in specific programs affected student specialization choices during this period and precluded analysis by program. It is noteworthy, however, that the percent of women students pursuing courses of study at this school primarily directed toward leadership and administration (educational administration, adult and continuing education, guidance and counseling, and higher education), increased during the 1970 s decade relative to several instructionally focused specializations.

\section{Collegiality}

Judging from continued professional associations, faculty appear to have 
TABLE 3. Fields of Specialization of Doctoral Students Over Two Decades

\begin{tabular}{|c|c|c|c|c|}
\hline & \multicolumn{2}{|c|}{$1964-70^{a}$} & \multicolumn{2}{|c|}{$1974-80^{b}$} \\
\hline & $\begin{array}{c}\text { Women } \\
\text { ( } \% \text { of } \\
\text { Sample) }\end{array}$ & $\begin{array}{c}\text { Men } \\
(\% \text { of } \\
\text { Sample) }\end{array}$ & $\begin{array}{c}\text { Women } \\
\text { (\% of } \\
\text { Sample) }\end{array}$ & $\begin{array}{c}\text { Men } \\
\text { (\%o of } \\
\text { Sample) }\end{array}$ \\
\hline Educational administration & 5.9 & 24.6 & 18.7 & 38.5 \\
\hline Adult and continuing education ${ }^{c}$ & 3.9 & 2.9 & 9.4 & 7.1 \\
\hline Curriculum and instruction ${ }^{d}$ & 27.5 & 20.8 & 14.0 & 12.1 \\
\hline Educational psychologye & 25.5 & 15.0 & 21.1 & 8.7 \\
\hline Guidance and counseling ${ }^{f}$ & 7.8 & 5.8 & 9.4 & 6.8 \\
\hline Higher education & 7.8 & 19.3 & 13.5 & 16.1 \\
\hline Occupational education & 0.0 & 0.5 & 1.2 & 2.8 \\
\hline Physical education & 15.7 & 4.8 & 2.9 & 1.2 \\
\hline Social foundations & 3.9 & 3.9 & 1.8 & 1.2 \\
\hline \multirow[t]{2}{*}{ Special education ${ }^{g}$} & 2.0 & 2.4 & 8.2 & 5.3 \\
\hline & $\overline{100.0}$ & $\overline{100.0}$ & 100.2 & $\overline{99.8}$ \\
\hline
\end{tabular}

${ }^{a} N=51$ women; 207 men.

${ }^{b} N=176$ women; 322 men.

${ }^{c}$ Includes education and community development.

${ }^{d}$ Includes early childhood education, educational technology, English and education.

${ }^{e}$ Includes two different programs in educational psychology.

$f_{\text {Includes rehabilitation counseling in 1974-80. }}$.

${ }^{g}$ Includes speech and hearing science in 1974-80.

been about equally accessible to both genders of students. Fifty-three percent of women students and $51 \%$ of the men students from the 1960 s mentioned at least one faculty member with whom they remain in contact. In the $1970 \mathrm{~s}$, the comparable percentages were $56 \%$ of women and $60 \%$ of men. ${ }^{4}$ The higher percentage for the 1970s reflects, we assume, the recency of graduate study. Despite similarities in these overall percentages, women graduates mentioned women faculty members far more frequently. For women graduates of the $1960 \mathrm{~s}$, women faculty members comprised $22.2 \%$ of the mentions, whereas only $3.6 \%$ of the names mentioned by men graduates were those of women faculty. In the 1970s, women graduates mentioned women faculty $18.4 \%$ of the time, and men graduates mentioned women faculty only $6.2 \%$ of the time. Such a pattern cannot be explained by field of specialization, as, particularly in the 1970 s, women enrolled heavily in programs with high percentages of male faculty.

\section{Career Patterns}

Table 4 describes the distribution, by sex and decade, of the occupational 
TABLE 4. Occupational Level Before and After Receipt of Doctoral Degree by Sex and Decade of Graduation

\begin{tabular}{|c|c|c|c|c|}
\hline & \multicolumn{2}{|c|}{$1964-70$} & \multicolumn{2}{|c|}{$1974-80$} \\
\hline & Women & Men & Women & Men \\
\hline \multicolumn{5}{|c|}{ I. Occupational Level Before Doctoral Studya } \\
\hline Highest level & 13.7 & 6.3 & 1.7 & 5.9 \\
\hline High level & 23.5 & 28.2 & 32.0 & 31.9 \\
\hline Medium level & 56.9 & 53.9 & 53.7 & 50.9 \\
\hline Low level & 2.0 & 6.3 & 6.3 & 5.9 \\
\hline \multirow[t]{2}{*}{ Lowest level } & 3.9 & 5.3 & 6.3 & 5.3 \\
\hline & & $\begin{array}{l}p=.30 \\
\text { Decades }\end{array}$ & $\begin{array}{l}X_{4}^{2}=4.92 \\
=.26\end{array}$ & $=.30$ \\
\hline
\end{tabular}

II. Occupational Level at Time of Survey

$\begin{array}{lccrr}\text { Highest level } & 12.2(11.8)^{c} & 23.2(22.7) & 6.3 & 16.8 \\ \text { High level } & 63.4(58.8) & 60.3(58.5) & 54.3 & 51.4 \\ \text { Medium level } & 22.0(27.4) & 10.8(13.0) & 31.4 & 29.0 \\ \text { Low level } & 0.0(0.0) & 2.6(2.9) & 2.3 & 1.6 \\ \text { Lowest level } & 2.4(1.9) & 3.1(2.9) & 5.7 & 1.2 \\ & X_{4}^{2}=6.37, p=.17 & X_{4}^{2}=18.35, p=.00\end{array}$

III. Distribution of changes in occupational level ${ }^{d}$

\begin{tabular}{rrrrr}
+4 & 0.0 & 1.0 & 0.0 & 0.3 \\
+3 & 2.4 & 4.7 & 1.7 & 5.0 \\
+2 & 9.8 & 15.0 & 7.5 & 8.2 \\
+1 & 39.0 & 41.5 & 31.6 & 34.5 \\
0 & 31.7 & 29.5 & 50.0 & 42.3 \\
-1 & 14.6 & 4.1 & 4.6 & 6.9 \\
-2 & 2.4 & 3.1 & 3.4 & 2.5 \\
-3 & 0.0 & 0.5 & 1.1 & 0.3 \\
-4 & 0.0 & 0.5 & 0.0 & 0.0 \\
\multicolumn{4}{c}{$X_{8}^{2}=7.86, p=.10$} & $X_{8}^{2}=5.49, p=.24$ \\
& & Decades: $X_{8}^{2}=17.94, p=.00$ &
\end{tabular}

$a_{N \text { s }}$ for $1964-70$ graduates $=51$ women, 207 men; $N$ for $1974-80$ graduates $=176$ women, 322 men.

${ }^{b}$ Range of years from time of degree to survey is 12 to 18 years for 1964-70 graduates; 2 to 8 years for $1974-80$ graduates. $N \mathrm{~s}$ for $1964-70$ graduates $=41$ women, $194 \mathrm{men} ; N \mathrm{~s}$ for $1974-80$ graduates $=175$ women, $321 \mathrm{men}$.

cGraduates who had retired ( $N=10$ women and $13 \mathrm{men})$ were not included in the analysis. Figures in parentheses show the distribution at each occupational level for the 1960s decade if these individuals reported the position they held before the doctorate and the one they occupied just prior to retirement.

${ }^{d} N$ s for $1964-70$ graduates $=41$ women, 194 men; $N$ for $1974-80$ graduates $=175$ women, 321 men. 
level indices we assigned to each person's job title just prior to beginning doctoral study (Table 4, Section I) and at the time of the survey (Table 4, Section II). Twenty-six individuals who had retired were included in the distribution of jobs prior to doctoral study but eliminated from the analysis of current job titles. (See Appendix 1 for the distribution of actual job titles).

Overall, there were no statistically significant differences in the distributions by occupational level between men and women at the time they began doctoral study in either decade or, for all students, across decades. Nonetheless, a slightly higher proportion of women students of the 1960 s held highest level positions, and a slightly smaller proportion held lowest level positions before entering doctoral study than was true for women students of the 1970s. The distributions of occupational level for men students were quite similar for the two decades.

As one would expect, the 1960s graduates, regardless of gender, currently hold positions of significantly higher level than graduates of the $1970 \mathrm{~s}$ $\left(X_{4}^{2}=26.85, p=.00\right)$. Overall, men and women graduates of the 1960s (mean years since degree 14.53 years for men and 14.56 years for women) were proportionately distributed over the occupational levels in similar fashion $\left(X_{4}^{2}=6.37, p=.17\right)$. Nonetheless, men graduates were roughly twice as likely as women to occupy either the highest or the two lowest level positions. Among graduates of the 1970s (mean years since degree 4.98 years for men; 4.41 years for women), the occupational distribution for men, as a group, was significantly different than that for women $\left(X_{4}^{2}=18.35, p=.00\right)$. More women graduates of the 1970 s remain in the lowest level positions, and a smaller percentage of women than men had reached the highest level.

We analyzed change in occupational level by subtracting each individual's predoctoral job index from the current index. Table 4 (Section III) reports the distribution of change (magnitude and direction) for individuals in each of the four subsamples. Although an individual may have changed jobs or job settings, a change of zero indicates no movement up or down the occupational level scale since doctoral study. This was the case for $31.7 \%$ of the women and $29.5 \%$ of the men who graduated in the $1960 \mathrm{~s}$ and for $50.0 \%$ of the women and $42.3 \%$ of the men who graduated in the $1970 \mathrm{~s}$. A negative change indicates that a graduate is now employed at a lower occupational level. Negative changes occurred infrequently for all groups, and for 1970s women (after homemakers [1.1\%] have been eliminated from consideration) may be largely accounted for by those indicating unemployment $(4.0 \%$, see Appendix 1) after doctoral study. A positive change indicates progress "up the career ladder" of the type that might normally be expected to accompany the increased status and expertise assumed to derive from the doctorate, as 
well as the passage of time following receiving the degree. The only statistically significant difference after retirees have been excluded is the one that would be expected between individuals who graduated a decade apart. Summing the percentage of graduates with positive change scores, we note that the least such progress was exhibited by the women graduates of the $1970 \mathrm{~s}$ $(40.8 \%)$, less than their male peers $(48.0 \%)$. The greatest percent change was for men of the $1960 \mathrm{~s}(62.2 \%)$, whereas only $51.2 \%$ of women graduates of the 1960 s exhibited positive change. In both decades, although the differences are not statistically significant, women graduates lag slightly in exhibiting upward career change.

We also determined how many individuals had changed the educational sector in which they work (See Table 5). To simplify our analysis, we combined three infrequent noneducational work sectors (business, government agency, and "other" employment settings). This consolidation produced three possible sectors in which individuals might maintain employment (Table 5, Section I) and six possible changes of sector (Table 5, Section II). Among graduates of the $1960 \mathrm{~s}, 47.6 \%$ of the women and $52.3 \%$ of the men had changed sectors, whereas for the 1970 s graduates, $31.9 \%$ of the women and $30.4 \%$ of the men had changed. Changes of sector were more frequent for the $1960 \mathrm{~s}$ graduates than for 1970 s graduates $\left(X_{8}^{2}=62.88, p=.00\right)$ but the proportion of changers was not significantly different for men and women within each decade.

The most frequent shift identified for all groups was from the other two sectors to higher education. For the 1960 s graduates, more men $(40.9 \%)$ than women $(31.0 \%)$ shifted sectors to higher education, whereas the shift for the two sexes was similar for the 1970 s graduates; $15.2 \%$ of the $1970 \mathrm{~s}$ men and $16.5 \%$ of the women shifted to higher education. Since a larger percentage of women than men in both decades were already working in higher education prior to doctoral study, the end result is that $73.9 \%$ of the women of the $1960 \mathrm{~s}$ (as compared to $67.8 \%$ of the men and exclusive of retirees) and $53.2 \%$ of the women of the 1970 s (as compared to $43.5 \%$ of the men) were working in higher education settings at the time of the survey.

\section{Perceived Impact of Doctoral Degree on Career}

Graduates' perceptions of the impact of receiving the doctoral degree upon various aspects of their career progress are given in Table 6. Graduates consistently perceived the greatest impact to be increases in personal satisfaction and professional knowledge and the smallest impact to be increases in salary and job security. Not unexpectedly, graduates of the 1960 s decade rated the impact of doctoral study on their careers to be significantly greater 
TABLE 5. Percent of Men and Women Graduates in Two Decades Who Changed or Did Not Change Work Sector After Doctorate

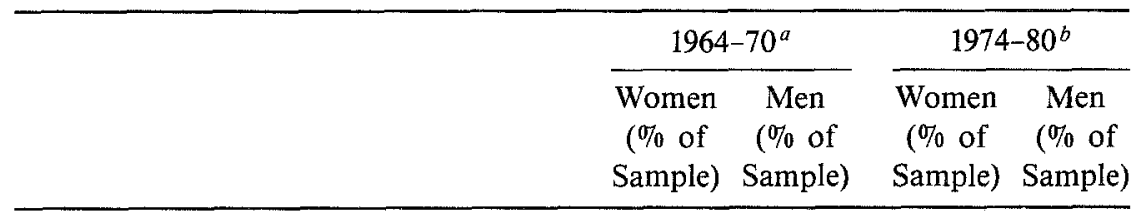

I. Remained in same sector

Remained in elementary/secondary education

Remained in higher education

Remained in gov't, business, community or other setting

$\begin{array}{rrrr}4.8 & 18.1 & 23.1 & 32.1 \\ 42.9 & 26.9 & 36.7 & 28.3 \\ \frac{4.8}{52.5} & \frac{2.6}{47.6} & \frac{8.3}{68.1} & \frac{9.2}{69.6}\end{array}$

II. Changed institutional sector

From elementary/secondary to higher education

$\begin{array}{llll}26.2 & 31.6 & 11.8 & 9.5\end{array}$

From elementary/secondary education to gov't, business, community or other setting

From higher education to elementary/ secondary education

$\begin{array}{cccc}7.1 & 5.2 & 4.7 & 4.8 \\ 0.0 & 1.6 & 1.2 & 1.9 \\ 9.5 & 4.1 & 7.7 & 7.0 \\ & & & \\ 0.0 & 0.5 & 1.8 & 1.6 \\ \frac{4.8}{47.6} & \frac{9.3}{52.3} & \frac{4.7}{31.9} & \frac{5.7}{30.4} \\ X_{8}^{2}=11.64, p=.17 & \begin{array}{c}X_{8}^{2}=6.8, p=.54 \\ \text { Decades: } X_{8}^{2}=62.88, p=.00\end{array}\end{array}$

From higher education to gov't, business, community or other setting

From gov't, business, community or other setting to elementary/secondary education

From gov't, business, community or other setting to higher education

$$
\begin{array}{cccc}
\frac{4.8}{47.6} & \frac{9.3}{52.3} & \frac{4.7}{31.9} & \frac{5.7}{30.4} \\
X_{8}^{2}=11.64, p=.17 & X_{8}^{2}=6.8, p=.54
\end{array}
$$

${ }^{a} N=41$ women; 194 men.

${ }^{b} N=175$ women; 321 men.

in all areas than did the 1970 s graduates who had received their degrees quite recently. Perceptions of degree impact on career were not significantly different by gender in either decade.

\section{Relation of Career Patterns and Career Progress Perceptions to Other Factors}

We conducted four hierarchical multiple regressions by sex and decade to 


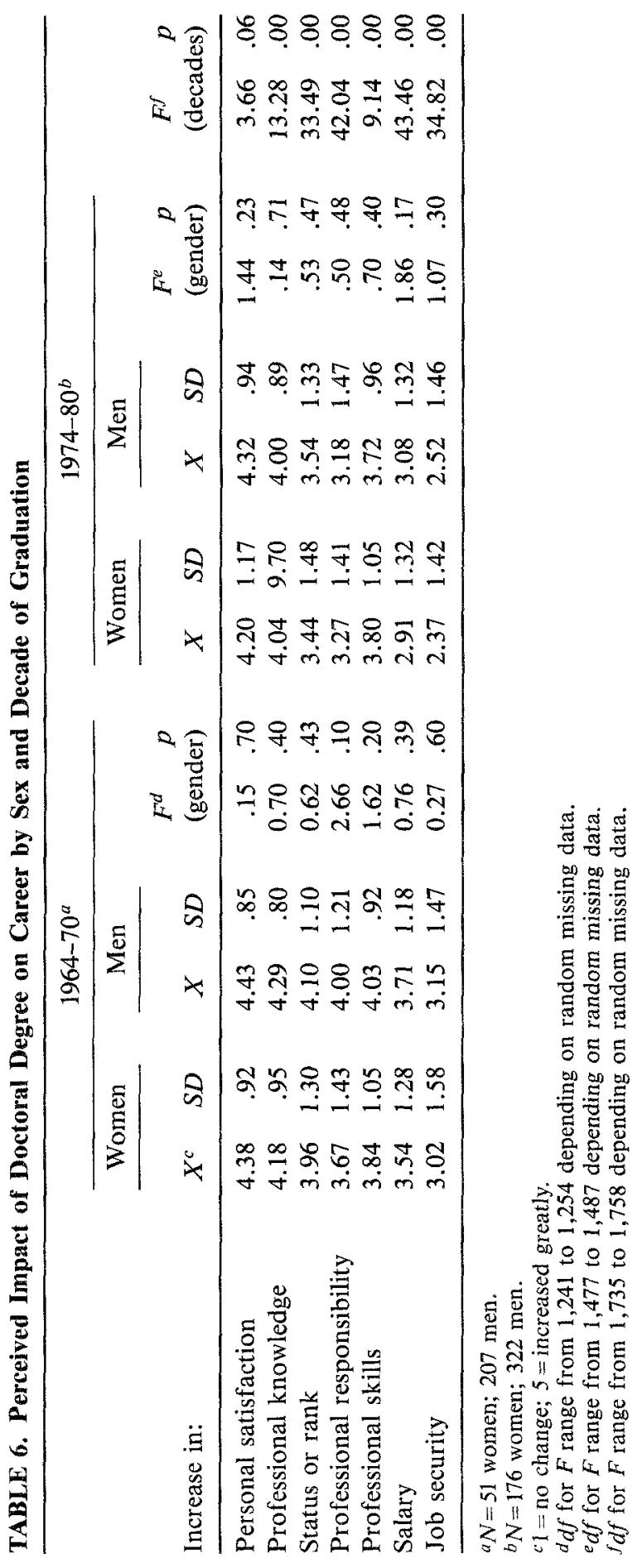


TABLE 7. Regression on Occupational Change Index

\begin{tabular}{lccccc}
\hline & \multicolumn{2}{c}{$1964-70^{a}$} & & \multicolumn{2}{c}{$1974-80^{b}$} \\
\cline { 2 - 3 } \cline { 5 - 5 } Women & Men & & Women & Men \\
\hline Statistical significance & 52.6 & 44.6 & 34.5 & 46.4 \\
$\quad F_{4,35}=9.71$ & $F_{4,183}=36.82$ & $F_{4,161}=21.21$ & $F_{4,307}=66.53$ \\
$\quad$ Beta weights & & & & \\
$\begin{array}{l}\text { Occupational level before } \\
\text { doctoral study }\end{array}$ & $-.64^{*}$ & $-.65^{*}$ & & $-.60^{*}$ & $-.68^{*}$ \\
$\begin{array}{l}\text { Work pattern during study } \\
\text { Age at receipt of degree }\end{array}$ & .05 & .02 & & -.02 & .02 \\
$\begin{array}{l}\text { Change of institutional } \\
\text { sector }\end{array}$ & -.17 & -.02 & & -.06 & .03 \\
\hline
\end{tabular}

${ }^{a} N=51$ women; 207 men.

${ }^{b} N=176$ women; 322 men.

$* p<.05$.

examine the possibility that change in occupational level was related to employment/support pattern during doctoral coursework, to age when the degree was received, to occupational level prior to doctoral study and to a change in institutional work sector. The results are shown in Table 7.

In each subsample and for all groups, occupational level before degree study was a significant predictor of change in occupational level following receipt of degree. Age at degree, change in institutional sector (entered as a dummy variable), and pattern of study/employment made no significant contributions. The best prediction was for women graduates of the 1960s, for whom $52.6 \%$ of the variance in occupational change was predicted by the variables used. In the case of these women, being older at receipt of degree played a recognizable but statistically nonsignificant part in prediction. The weakest prediction (34.5\% of the variance) was for women graduates of the 1970s. Prediction for men graduates was similar in both decades.

Despite its lack of importance as a predictor of occupational change level, the rather frequent shifts in institutional work sector for both men and women graduates prompted us to examine more closely the mean career impact perceived by those who changed settings and those who remained in their original type of work (Table 8). For women, only one perceived career impact, professional status, differed significantly for changers and nonchangers. Those who had changed settings were slightly more likely to feel that their professional status had increased. For men graduates, significant differences were found between changers and nonchangers on all perceptions of career impact except personal satisfaction. In every case, those men 


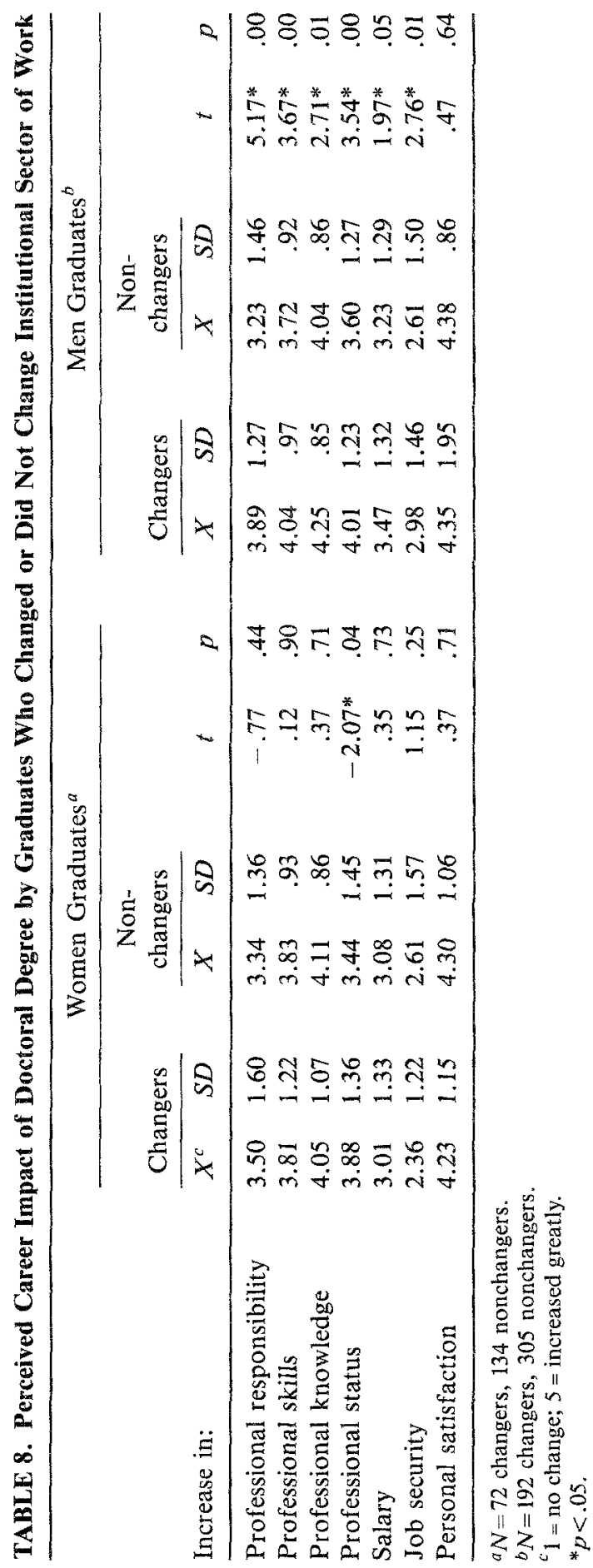


who changed settings credited the doctoral degree with a greater positive impact on their career.

Similarly, using one-way analysis of variance, we compared responses of men and women graduates who, at the time of the survey, were working in elementary/secondary education, in higher education and in business, government, or other settings (Table 9). Again, for women, few significant differences appeared. Women working in elementary/secondary education were slightly more likely to perceive that the doctorate increased their professional knowledge and professional skills than women working in other settings, but the groups did not differ in their views of the impact of the doctorate on other job-related factors such as status, professional responsibility, salary, or job security. For men, on the other hand, the three groups working in different settings perceived the degree impact differently for all job factors except personal satisfaction and professional skills. For all but one of the variables where differences were statistically significant, men working in higher education were most likely to assess the doctorate as having highest career impact and men working in elementary/secondary education perceived the smallest career impact. In the case of the single exception, salary, men working in business/government or other settings perceived the doctorate as having greater impact than did those working in either higher or elementary/secondary education.

\section{DISCUSSION}

Analysis of survey data from doctoral graduates in education, one group of whom received degrees when women doctorates constituted a definite minority, and the second group of whom received degrees when the percent of women doctorates was increasing rapidly, showed little evidence of institutionally based discrimination against women during graduate study. University statistics reveal that a slightly greater percentage of women applicants than men was admitted to graduate study in education. ${ }^{5}$ Self-report data from our respondents indicated that women had a slight edge in receiving assistantships and in obtaining personal and financial support for full-time study. Although the percentage of students receiving financial support in education decreased substantially during the decade of the 1970s, when both the number of doctoral students and the percentage who were women was on the upswing, women retained their competitive position. Men retained full-time employment more frequently during the 1970 s, believing more often than women that it was necessary to do so because of family responsibilities.

Based on reports of continued contact, a proxy measure of faculty accessibility and collegiality, men and women doctoral students in education 


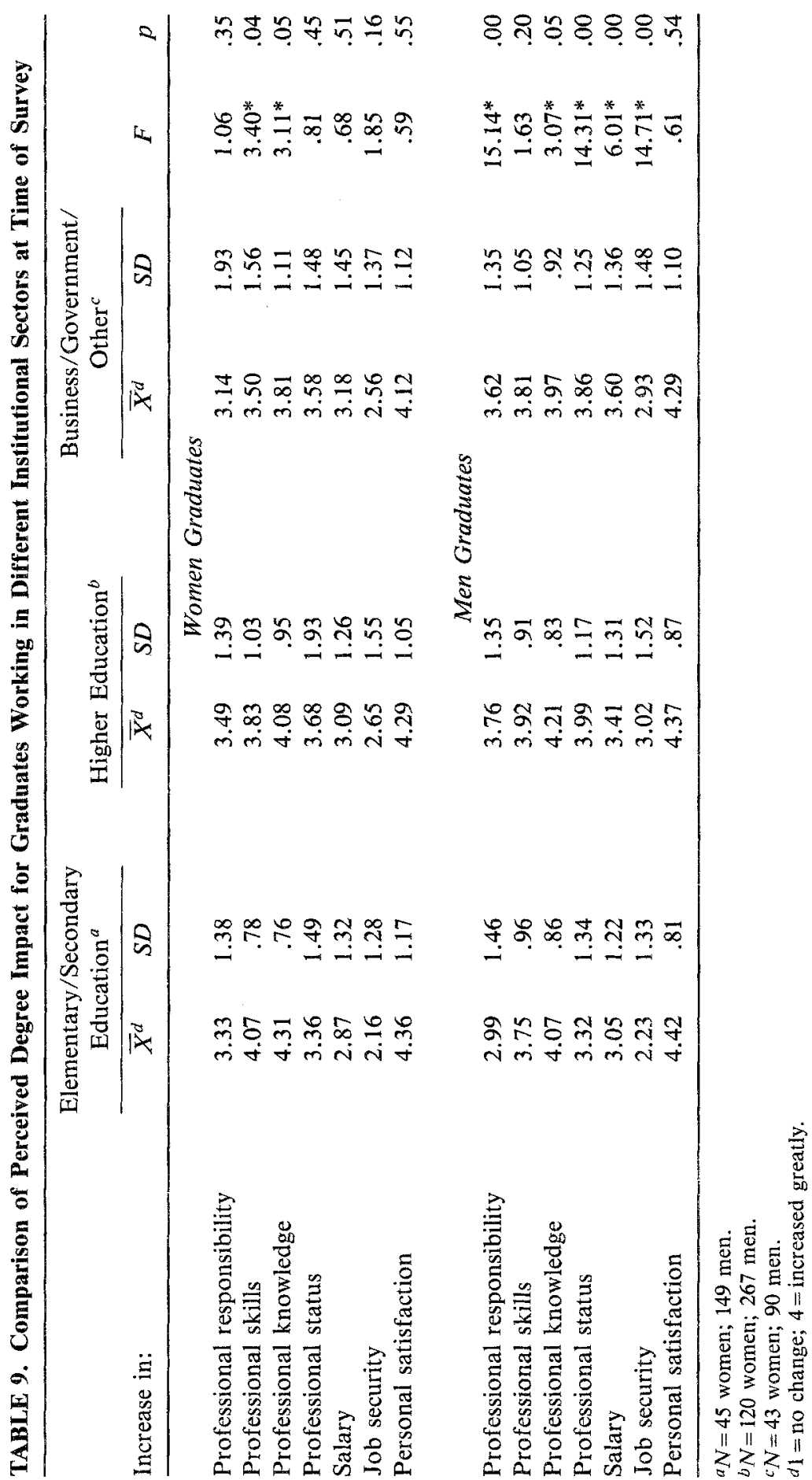


formed close relationships with faculty members to about the same degree, although women graduates far more frequently reported continuing relationships with women faculty. These results confirm research indicating an affiliation of same-gender graduate students and faculty members. In our study, however, because at least three-quarters of available faculty were men, the data do not provide clear evidence for Berg and Ferber's (1983) speculation that men students may be disadvantaged in traditionally female fields.

Despite their slightly more advantageous position relative to men in admission, financial support and full-time study for the doctorate, women graduates of both decades examined had not achieved quite the same levels of career progress as had their male colleagues. Although the overall gender differences were not statistically significant, the men graduates of the 1964-70 period had more frequently achieved the highest level positions and, based on changes in an index of occupational level, a slightly higher percentage of men reported upward career advancement. The gender-related career progress differentials found among 1960s graduates had not been eliminated for graduates of the 1974-80 period. In fact, four years after receiving the doctorate, women graduates of the 1970s appeared to show less upward career progress and to lag further behind their male colleagues in terms of level of position achieved than did women graduates of the 1960s after fourteen years. Although the passage of time may eliminate some gender-related differences, it is difficult to detect substantial results of affirmative action policies in education based only on an analysis of job titles four years after the receipt of the doctorate.

A conclusion that affirmative action has not been effective may be too simplistic, however, if it does not account for changes in the types of students pursuing the doctoral degree. Women doctoral students of the 1960 s tended to be significantly older than men and at least as firmly established in their careers. They often pursued doctoral study after having risen to substantial levels of responsibility in education. In contrast, women doctoral graduates of the 1970s undertook their degree study at an age more comparable to their male colleagues and at a slightly earlier employment stage than 1960 s women. Regression analysis indicated that, among a limited set of predictors available for examination, the strongest predictor of occupational advancement for both men and women graduates was level of position held prior to doctoral study. Prediction was strongest for women graduates of the 1960s and weakest for women graduates of the 1970s. If predictions were based on a regression equation generated from the experience of 1960s women graduates, the younger and less experienced women doctorates of the 1970 s might be viewed as lagging even farther behind their male contem- 
poraries. For these recent women graduates, other factors not in our data set - quite possibly new opportunities generated by affirmative action - may have been compensating factors, while simultaneously, a weak job market was a negative influence.

In the public school sector, for example, the percentage of women from the 1970s graduates holding positions of superintendent, assistant or associate superintendent, supervisor, principal and assistant principal nearly doubled from $6.9 \%$ to $12.0 \%$ following receipt of the doctorate. Men's proportion of the same positions increased only from $20.7 \%$ to $24.8 \%$. Nonetheless, although women's enrollment in specializations directed at public school leadership posts increased, we found little clear evidence that the field of public school administration currently can accommodate women's higher levels of aspiration. In fact, many women from both decades availed themselves of opportunities in the field of higher education. Among most recent graduates, a higher percentage of women than men moved from public school work to college or university work. It is impossible to determine if such movement across sectors is the cause or effect of the continuing small number of women in public school leadership positions.

The chance exists that a response bias is present in our survey despite a rather high response rate for a survey of this type. We did not conduct tests for response bias. We note that Ferber and Kordick (1978) found, particularly for women, that graduates who answered a second-wave shorter follow-up survey were likely to be in higher paying, more responsible positions. Presumably, their busy lives caused delay in responding. If the response bias were in the direction Ferber and Kordick (1978) reported, it is possible that the slight career progress differences among men and women graduates in our study would be eliminated. If the bias were in the opposite direction, we would be forced to conclude that women in education, a rapidly increasing proportion of those with advanced degrees, continue to find less-rapid career advancement than men.

Our data do not support the finding of Berg and Ferber (1983) that men graduates were more satisfied with their job opportunities and salary progress than were women graduates. Overall, our women respondents were as satisfied as men with the career impact of doctoral study. Women obtained considerable personal satisfaction from receiving the degree, and, more importantly, believed to the same extent as men that it had resulted in career improvement. In contrast to our expectations, it was men graduates for whom a change in institutional work sector was associated with higher perceived career impact on nearly all dimensions. Additionally, men graduates working in elementary/secondary education were most likely to view receipt of the degree as having less substantial career impact than those 
working in other sectors. Women, in comparison, seemed to perceive similar career impact regardless of the sector in which they were employed or whether they had changed sectors.

Several explanations are possible for the consistently high impact assessment made by women who, generally, have not achieved quite the same career progress as men. One possibility is that women optimistically view themselves as prepared for advancement opportunities that may arise in the future, whereas their male colleagues feel more severely the combined effect of a slack job market and affirmative action policies, particularly in elementary/secondary education settings. Another possibility is suggested by evidence that women have lower self-concepts and set lower goals for themselves (Berg and Ferber, 1983) or have lower career aspirations (Shann, 1983) leading to perceived impact without substantiated career progress comparable to that of men. Still another possibility is suggested by our findings, paralleling those of Centra (1975) and of Ferber and Kordick (1978), that prior experience is important in career advancement. Clearly, a previous responsible position, coupled with a doctorate, may be most predictive of career progress for both men and women. The younger, somewhat less experienced, women graduates of the 1970 s may appear satisfied with career progress because more opportunities have been opened to them than they had originally envisioned.

Previously researchers (Wong and Sanders, 1983; Ferber and Kordick, 1978) have referred in their studies of women and men doctorates to the separate "human capital" and "discrimination" schools of thought regarding gender differences in graduate study and employment. Human capital includes qualifications - such as prior academic success, publications, and work experience acquired both in and out of the university - that may influence career progress. Lack of career progress based on findings of limited "human capital" imply different solutions for inequities than does lack of progress based on discrimination. Except for Ferber and Kordick, few follow-up studies have taken into account "human capital" gained from work experience. Our results indicate that, regardless of the presence or absence of discrimination, women may need to acquire more human capital to advance as rapidly as men even in a field of study traditionally viewed as female-dominated. Such a finding surely points to the importance of internship experiences for women doctoral students seeking leadership posts in public elementary and secondary schools and of scholarly activities for those seeking university work.

In analyzing the rapid increase in educational level for women in all fields, Roemer (1983) predicts that the remaining gender disparities in degrees granted may eventually be eliminated. Nevertheless, despite elimination of disparities at the training institutions, gender disparities may still exist in the 
career patterns of men and women. If the fields women desire to enter do not typically involve work experience during graduate training, and the expectations of women increase, the dissatisfaction of women who have paid tuition and worked for advanced degrees also may increase. Since entry level and second level jobs in education have long been equally available to men and women, acquisition of necessary human capital seems somewhat easier to ensure in education than in business, government, and industry, where salary and responsibility discrepancies are reported to be even greater (Centra, 1975). In fields other than education, it may be more difficult for women to acquire the work experience that predicts full use of doctoral study.

\section{NOTES}

1. Individuals pursuing graduate level degrees in education frequently have received bachelor's degrees in other fields. Consequently, it is not meaningful to calculate percentages of the bachelor's cohort who pursue advanced study, as is sometimes done for the disciplines.

2. Because the survey was originally designed for other purposes, some data were unavailable that might have helped relate the findings to previous research. This was particularly true regarding personal concerns during graduate study, as marital status, number of dependents, and related personal circumstances are unknown.

3. The patterns described do not necessarily form a continuum from professionally related work to non-professionally related work. In fact, Pattern 3 includes both individuals who held part-time professional positions in local educational institutions or within the university and individuals who pursued unrelated occupations for financial support. This group, however, may be presumed to be less fully involved in doctoral study than those classified in Patterns 1 and 2, but more fully involved than was possible for those in Pattern 4, who continued full-time positions.

4. Calculations were based on percentage of mentions rather than the percentage of education faculty who were women, as students mentioned faculty contacts from many other fields making an appropriate universe the entire university faculty. Midway through the period studied, the university employed $15.2 \%$ women faculty at all ranks (University of Michigan, Rackham Graduate School, 1974) whereas the percent of education faculty who were female ranged between $17 \%$ and $26 \%$ during the period of the study. Of the 262 faculty members mentioned, 136 held either full- or part-time faculty appointments in the School of Education in the fall immediately following the study, 339 were emeritus education professors, and 87 were faculty with either past or current appointments in other tniversity units.

5. Although admission statistics specifically for our sample were unavailable, a special report of the university's graduate school compiled for a period within the two decades studied indicate that women applicants received slightly more than their proportionate share of admissions in education (38\% of applicants and $44 \%$ of the admission offers) (University of Michigan, Rackham Graduate School, 1974.)

\section{REFERENCES}

Ahren, N. C. and Scott, E. L. (1981). Career Outcomes in a Matched Sample of Men 
and Women Ph.D.s: An Analytical Report. Washington, D.C.: National Academy of Sciences, National Research Council.

Berg, H. M. and Ferber, M. A. (1983). Men and women graduate students: Who succeeds and why? Journal of Higher Education 54(6): 629-648.

Biklen, S. K., and Brannigan, M. B. (1980). Women and Educational Leadership. Lexington, Mass.: D.C. Heath.

Broschart, K. R. (1978). Family status and professional achievement: A study of women doctorates. Journal of Marriage and the Family 40(1): 71-76.

Centra, J. A. (1975). Women with doctorates. Change 7(1): 49, 61.

Denmark, F. L. (1978). Women in psychology in the United States. Resources in Education, ED 171166.

Ekstrom, R. B. (1979). Women faculty: development, promotion and pay. ETS Findings 5: 2 (Princeton, N.J.: Educational Testing Service).

Ferber, M. A., and Kordick, B. (1978). Sex differentials in earnings of Ph.D.s. Industrial and Labor Relations Review 31 (2): 227-238.

Gappa, J. M., and Uehling, B.S. (1979). Women in Academe: Steps to Greater Equality. Washington, D.C.: American Association for Higher Education. ERIC/ AAHE Research Report No. 1.

Hansot, E., and Tyack, D. (1982). The golden age for school administrators? The Stanford Educator, Fall.

Hartnett, R. T. (1981). Sex differences in the environment of graduate students and faculty. Research in Higher Education 14(3): 211-228.

Holahan, C. K. (1979). Stress experienced by women doctoral students, need for support and occupational sex typing: An interactional view. Sex Roles: A Journal of Research 5(4): $425-436$.

Hornig, L. (1980). Climbing the Academic Ladder: Doctoral Women Scientists in Academe. Washington, D.C.: National Academy of Sciences. National Research Council. May.

Lorang, W. G., and Terenzini, P. T. (1982). Discipline-related differences among recent doctoral degree recipients. Paper presented at the forum of the Association for Institutional Research, Denver.

Malin, J. T., Bray, J. H., Dougherty, T. W. and Skinner, W. K. (1980). Factors affecting the performance and satisfaction of adult men and women attending college. Research in Higher Education 13(2): 115-130.

Randour, M. L., Strausberg, G. L., and Lipman-Blumen, J. (1982). Women in higher education: trends in enrollment and degrees earned. Harvard Educational Review 52: $189-202$.

Roemer, R. E. (1983). Changing patterns of degree selection among women: 1970-78. Research in Higher Education 18(4): 435-454.

Shann, H. (1983). Career plans of men and women in gender-dominant professions, Journal of Vocational Behavior 22: 343-346.

Solmon, L. C. (1973). Women in doctoral education: clues and puzzles regarding institutional discrimination. Research in Higher Education 1(4): 299-332.

Tidball, M. E. (1976). Of men and research: the dominant themes in American higher education include neither teaching nor women. Journal of Higher Education 47(4): $373-389$. 
University of Michigan, Horace H. Rackham Graduate School (1974). The higher, the fewer. Report of a committee to study the status of women in graduate education and later careers. Ann Arbor: The University of Michigan.

University of Michigan (1983). Surviving and thriving in graduate and professional school: Women at the university. Center for Continuing Education of Women Newsletter 11: 1.

Wong, H. Y. and Sanders, J. M. (1983). Gender differences in the attainment of doctorates. Sociological Perspectives 26(1): $29-50$.

Received January 25, 1985 

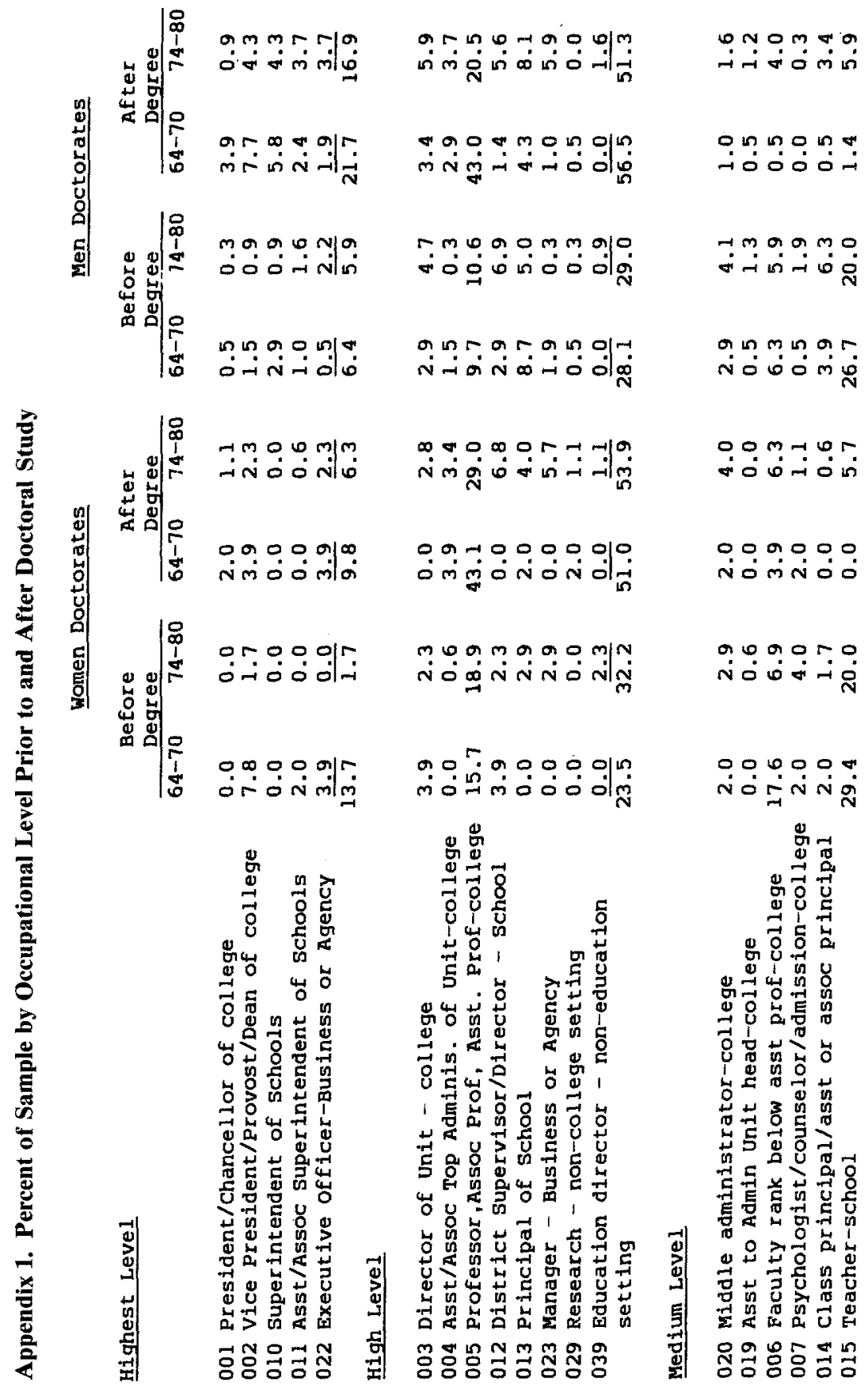


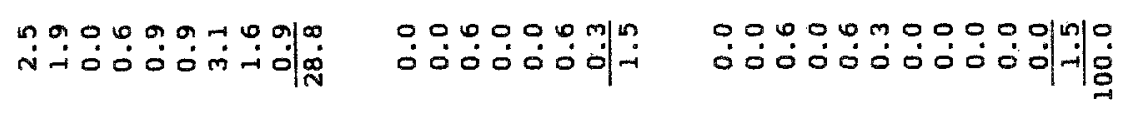

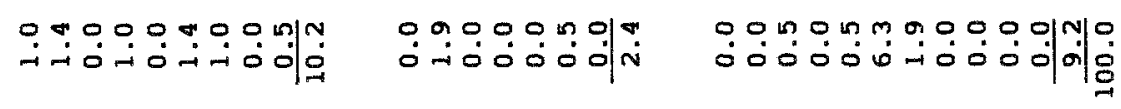

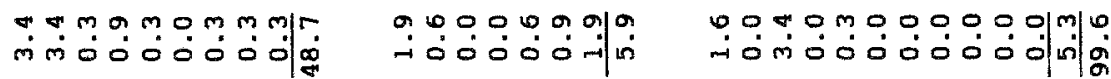

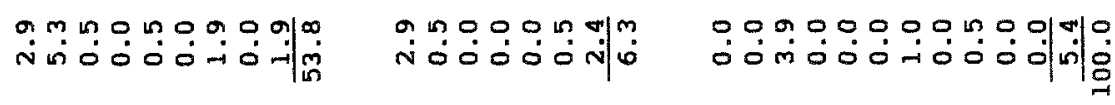

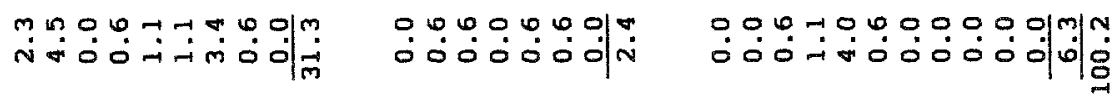

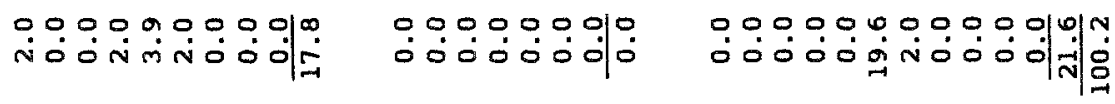

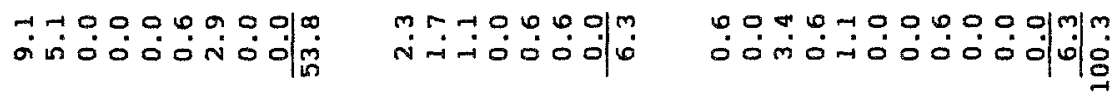

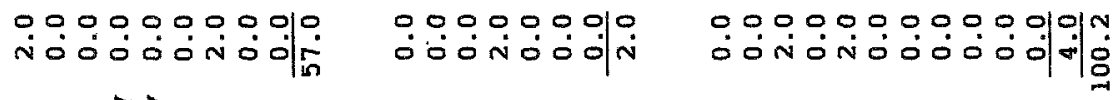

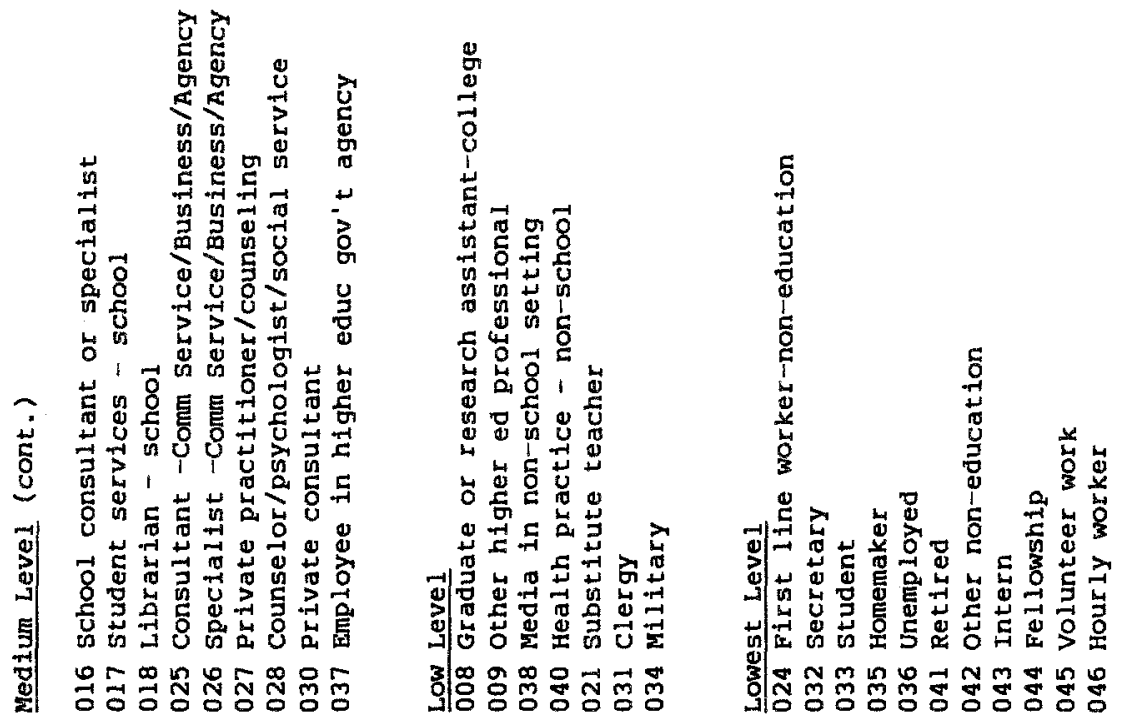

